\title{
ANALISIS TINGKAT RESIKO DAMPAK GEMPABUMI DI KABUPATEN CILACAP MENGGUNAKAN METODE DSHA DAN DATA MIKROTREMOR
}

\author{
Kukuh Dialosa*1, Rustadi ${ }^{1}$, Bagus S. Mulyatno ${ }^{1}$, Cecep Sulaeman ${ }^{2}$ \\ ${ }^{1}$ Jurusan Teknik Geofisika, Fakultas Teknik, Universitas Lampung \\ ${ }^{2}$ Pusat Vulkanologi dan Mitigasi Bencana Geologi, Badan Geologi, Kementerian ESDM \\ Jurusan Teknik Geofisika, FT UNILA \\ e-mail: *11 dialosa24@gmail.com
}

\begin{abstract}
ABSTRAK
Telah dilakukan penelitian mekanika tanah di Kabupaten Cilacap menggunakan metode DSHA dan data mikrotremor. Penelitian ini bertujuan untuk menganalisis respon tanah setempat terhadap gempabumi berdasarkan parameter frekuensi dominan (f0), faktor amplifikasi (A0), kecepatan gelombang VS30 dan analisis bahaya gempa melalui pendekatan deterministik. Penelitian menggunakan 193 titik pengukuran mikrotremor dengan menggunakan alat ukur Seismometer periode pendek tipe TDS-303 (3 komponen). Data mikrotremor dianalisis menggunakan metode Horizontal to Vertical Spectral Ratio (HVSR) pada software geopsy. Analisis DSHA merujuk pada sumber gempa Patahan Lembang dan zona Subduksi Jawa untuk perhitungan deterministik. Berdasarkan analisis metode HVSR, Kabupaten Cilacap berada pada jenis tanah 1 (frekuensi 0$1,33 \mathrm{~Hz}$ ) dan jenis tanah 2 (frekuensi 1,33-5 Hz) menurut Klasifikasi Kanai (1983), didominasi nilai amplifikasi 1,104 sampai 8,171 kali, kemudian didominasi dengan kelas tanah E (nilai VS30 $<183 \mathrm{~m} / \mathrm{s}$ ) dan kelas tanah D $(183 \mathrm{~m} / \mathrm{s}<$ VS30 < $366 \mathrm{~m} / \mathrm{s})$ menurut Klasifikasi NEHRP (2000). Hal ini menandakan Kabupaten Cilacap memiliki kerentanan yang tinggi terhadap bencana gempabumi. Berdasarkan estimasi nilai PGA hasil perhitungan metode DSHA, dari perhitungan sumber gempa Subduksi Jawa didapat nilai PGA batuan dasar $0,045 \mathrm{~g}-0,0671 \mathrm{~g}$ dan PGA batuan permukaan $0,1926 \mathrm{~g}-0,4855 \mathrm{~g}$ serta perhitungan Patahan Lembang didapat PGA batuan dasar $0,09 \mathrm{~g}-0,025 \mathrm{~g}$ dan PGA batuan permukaan $0,017 \mathrm{~g}-0,089 \mathrm{~g}$. Berdasarkan analisis peta resiko (gabungan analisis frekuensi dominan, amplifikasi, faktor kerentanan dan faktor kemampuan) didapat daerah yang paling beresiko tinggi adalah Kec. Adipala, Kasugihan, Binangun, Nusawungun, Cil. tengah, Cil. Selatan, Cil. Utara, diduga lapisan tanah penyusun daerah tersebut adalah lapisan sedimen yang tebal dan lunak. Sedangkan resiko rendah Kec. Majenang dan Dayeuh Luhur.
\end{abstract}

\begin{abstract}
Soil mechanical research has been done in Cilacap Regency using DSHA method and microtremor data. This study aims to analyze the local land response to earthquakes based on the dominant frequency parameters (f0), amplification factor (A0), wave velocity VS30 and seismic hazard analysis through deterministic approach. This research uses 193 microtremor measurement points using a short period TDS-303 type (3 component) seismometer. Microtremor data were analyzed using the Horizontal to Vertical Spectral Ratio (HVSR) method in geopsy software. DSHA analysis refers to the source of the Lembang Fault earthquake and Java Subduction zone for deterministic calculations. Based on the analysis of HVSR method, Cilacap Regency is located on land type 1 (frequency $0-1.33 \mathrm{~Hz}$ ) and soil type 2 (frequency 1,33-5 Hz) according to Kanai Classification (1983), dominated amplification value 1,104 to 8,171 times, then Dominated by soil class E (VS30 value $<183 \mathrm{~m} / \mathrm{s}$ ) and soil class D (183 m / s <VS30<366 m / s) according to NEHRP Classification (2000). This indicates that Cilacap Regency has high vulnerability to earthquake disaster. Based on the estimated value of PGA calculation method of DSHA, from the calculation of earthquake source Subduction obtained Java PGA bedrock 0,045 $\mathrm{g}$ $0,0671 \mathrm{~g}$ and PGA surface rock 0,1926 g - 0,4855 g and calculation of Lembang Fault obtained PGA bedrock 0, $09 \mathrm{~g}-0.025 \mathrm{~g}$ and PGA surface rocks $0.017 \mathrm{~g}-0.089 \mathrm{~g}$. Based on risk map analysis (combination of dominant frequency analysis, amplification, susceptibility factor and ability factor), the highest risk areas are Kec. Adipala, Kasugihan, Binangun, Nusawungun, Cil. Middle, Cil. South, Cil. North, allegedly the soil layer constituent area is a layer of thick and soft sediments. While the low risk of Kec. Majenang and Dayeuh Luhur.
\end{abstract}

Keywords - Cilacap, dominant frequency, amplification, VS30, DSHA, PGA 


\section{PENDAHULUAN}

Salah satu bencana alam yang sering terjadi di Indonesia, yaitu gempabumi. Gempabumi dinyatakan sebagai goncangan tanah yang disebabkan oleh pelepasan energi kulit bumi secara tiba-tiba. Penyebab Indonesia memiliki intensitas gempa yang tinggi, yaitu letak Indonesia yang berada pada zona pertemuan antara tiga lempeng tektonik, yakni lempeng Eurasia, IndoAustralia, dan lempeng Pasifik.

Daerah perbatasan lempeng ini merupakan zona seismisitas yang aktif (Issack, 1968 dalam Kusumaningsih, 2004), yang membentang sepanjang tidak kurang dari $5600 \mathrm{~km}$ mulai dari Andaman sampai ke Busur Banda Timur, sehingga banyak terjadi gempabumi tektonik yang diakibatkan oleh tumbukan antar lempeng tersebut, dan sebab yang lainnya adalah karena aktivitas beberapa sesar lokal di daratan (Daryono, 2009).

Cilacap merupakan salah satu daerah yang berada di sisi selatan Pulau Jawa yang sering merasakan dampak dari guncangan gempabumi di zona tumbukan lempeng di selatan Jawa dan aktivitas patahan lokal di daerah Cilacap ( Susilanto dan Ngadmanto, 2014).

Setiap kejadian gempabumi menghasilkan goncangan tanah yang dapat diidentifikasikan melalui nilai percepatan getaran tanah pada suatu tempat. Semakin besar nilai percepatan getaran tanah yang terjadi disuatu tempat, semakin besar bahaya gempabumi yang mungkin terjadi. Besar kecilnya nilai percepatan getaran tanah tersebut menjadi salah satu faktor yang dapat menunjukkan tingkat risiko gempabumi.

\section{TINJAUAN PUSTAKA}

Lokasi penelitian terletak di Kabupaten Cilacap, Provinsi Jawa Tengah. Penelitian ini menggunakan data hasil akuisisi dari metode mikrotremor untuk menganalisis respon tanah setempat terhadap gempabumi berdasarkan parameter frekuensi dominan (fo), faktor amplifikasi (A0), kecepatan gelombang Vs30 dan estimasi nilai $P G A$ berdasarkan Patahan Lembang dan zona Subduksi Jawa. Terdapat 193 titik akuisisi mikrotremor di sekitar Kabupaten Cilacap.

Kerangka Tektonik Zona selatan Jawa merupakan bagian dari kerangka tektonik Indonesia. Daerah ini termasuk dalam jalur pertemuan lempeng yang bersifat konvergen, di mana Lempeng IndoAustralia, menyusup ke bawah Lempeng Eurasia dengan kecepatan 50 hingga 70 $\mathrm{mm} /$ tahun. Pada batas pertemuan lempeng ini ditandai dengan adanya palung samudera, terbukti dengan keberadaan Java Trench di Samudera Hindia. Sistem subduksi ini mulai menunjam kebawah disepanjang palung laut dalam. Sudut penunjaman lempeng atau disebut juga subdaksi adalah sekitar $20^{\circ}-30^{\circ}$ miring kearah pantai selatan Jawa dan palung ini biasa disebut sebagai patahan anjak besar atau Megathrust. Zona Megathrust adalah sumber gempabumi besar yang berpotensi memicu terjadinya tsunami seperti halnya gempabumi Aceh tahun 2004 dan gempabumi Pangandaran tahun 2006

Pergerakan Lempeng Indo-Australia terhadap Lempeng Eurasia mengakibatkan zona Selatan Jawa sebagai salah satu daerah yang memiliki tingkat kegempaan yang cukup tinggi di Indonesia berkaitan dengan aktivitas tumbukan lempeng (plate collision). Pergerakan lempeng ini menimbulkan struktur-struktur tektonik yang merupakan ciri-ciri sistem subduksi, seperti zona Benioff, palung laut, punggung busur luar (outer arc ridge), cekungan busur luar (outer arc basin), dan busur pegunungan (volcanic arc). Di samping sangat rawan gempabumi akibat aktivitas tumbukan lempeng, zona Selatan Jawa juga sangat rawan gempabumi akibat aktivitas sesarsesar lokal di daratan. Kondisi tektonik semacam ini menjadikan zona selatan Jawa sebagai kawasan seismik aktif (Daryono, 2015). Irsyam dkk. (2010) telah 
mengidentifikasi sumber-sumber gempa sesar di Pulau Jawa yang dapat digunakan untuk penilaian bencana seismik. Mereka telah membagi sistem sesar jawa pada 5 sesar yaitu: Cimandiri, Lembang, Opak, Pati dan Lasem. Segmen sesar yang berjarak paling dekat dan dianggap berpengaruh terhadap Kabupaten Cilacap adalah segmen Sesar Lembang.

Berdasarkan Gambar 1. peta geologi

Kabupaten Cilacap, Jawa Tengah (Modifikasi dari Djuri, 1995), wilayah Cilacap didominasi oleh formasi Halang yaitu endapan batuan yang berumur Miosen Akhir yang terdiri dari batupasir, andesit, konglomerat, tufan dan napal (Djuri, dkk., 1996), formasi Kumbang yang terdiri dari breksi gunungapi, lava dan konglomerat berumur Pliosen, formasi Tapak yang terdiri batupasir kasar berwarna kehijauan dan konglomerat yang juga berumur Pliosen, serta endapan yang paling muda yaitu endapan aluvial yang berumur Holosen.

\section{TEORI DASAR}

\subsection{HVSR}

Teknik H/V (HVSR) atau disebut juga QTS (Quasi-Transfer Spectra) telah mendapat perhatian besar dari seluruh dunia dengan kesederhanaan metodenya dan cepat dalam menyediakan informasi mengenai karakteristik dinamik tanah dan bangunan. Teknik H/V dikembangkan oleh penulis (Nakamura) dengan menghubungkan penyelidikan lubang bor terhadap analisa dari catatan-catatan gerakan tanah yang kuat, di berbagai kondisi geologi. Teknik ini sangat efektif untuk mengidentifikasi frekuensi resonansi dasar pada lapisan sedimen, dengan menyertakan faktor amplifikasi yang lebih realistis dibandingkan yang didapat dari rasio sedimen terhadap batuan keras. Telah ditunjukkan oleh banyak peneliti (seperti Ohmachi et. Al., 1991; Lermo et. Al., 1992; Field and Jacob, 1993, 1995 dalam
Nakamura, 2008) bahwa rasio H/V yang didapat dari noise dapat digunakan untuk mengidentifikasi frekuensi resonansi dasar dan faktor amplifikasi di lapisan sedimen.

\subsection{PGA}

Percepatan getaran tanah maksimum atau Peak Ground Acceleration (PGA) adalah nilai terbesar percepatan tanah pada suatu tempat yang diakibatkan oleh getaran gempa bumi dalam periode waktu tertentu. Kondisi geologis tanah yang sangat menentukan besarnya kecilnya nilai PGA adalah tingkat kepadatan tanah di daerah tersebut. Semakin padat tanah maka nilai PGA di daerah tersebut semakin kecil. Hal ini sesuai dengan kenyataan di lapangan bahwa bangunan yang dibangun di atas struktur tanah yang padat pada saat gempa bumi di Bengkulu yang terjadi pada tahun 2000 (7,3 SR) mengalami kerusakan lebih ringan daripada bangunan yang dibangun di atas struktur tanah yang kurang padat (Lubis dan Hadi, 2005 dalam Hadi dkk., 2012).

\section{METODE PENELITIAN}

\subsection{Tempat dan Waktu Penelitian}

Penelitian ini dilaksanakan pada tanggal 15 November 2016 - 15 Januari 2017. Tempat penelitian ini di Pusat Vulkanologi dan Mitigasi Bencana Geologi, Badan Geologi, Bandung.

\subsection{Data Penelitian}

Data yang digunakan pada penelitian ini yaitu data pengukuran mikrotremor di Kabupaten Cilacap, Jawa Tengah yang berjumlah 193 titik. Data ini diperoleh dari akuisisi yang dilakukan oleh Tim Pusat Vulkanologi dan Mitigasi Bencana Geologi pada bulan April dan September 2014. Sedangkan pada metode $D S H A$, parameter 
gempa bumi yang berupa jarak terdekat didapat dari hasil perhitungan antara site dan sumber gempa, kemudian parameter yang berupa magnitudo maksimum (MMax) didapatkan dari Tim Revisi Peta Gempa Indonesia (2010). Untuk parameter DSHA lainnya yang berupa $V S 30$ didapat dari pengolahan data mikrotremor.

\subsection{Tahapan Pengolahan Data}

Terdapat beberapa tahapan pengolahan data, yaitu:

\subsubsection{HVSR}

Dari akuisisi mikrotremor akan didapatkan data yang berupa data getaran tanah yang masih dalam domain waktu. Data getaran tanah itu merekam getaran dalam tiga komponen, yaitu satu komponen vertical dan dua komponen horizontal (utara-selatan dan barat-timur). Data hasil akuisisi yang didapat pada penelitian ini memiliki format berupa.$S A F$. Data tersebut kemudian diolah dengan metode HVSR (Horizontal Vertical Spectral Ratio) menggunakan perangkat lunak berupa Geopsy yang mengacu pada SESAME H/V Users Guidelines. Proses pengolahan pada geopsy akan menghasilkan keluaran berupa kurva spektrum $H V S R$ yang menunjukan parameter frekuensi dominan dan faktor amplifikasi.

\subsubsection{DSHA}

Tahap analisis seismic hazard dengan metode DSHA adalah sebagai berikut:

a. Melakukan identifikasi dan

karakterisasi

sumber-sumber gempa yang dimungkinkan akan berpengaruh pada lokasi penelitian.

b. Menentukan parameter jarak terdekat dari sumber gempa terhadap lokasi penelitian. c. Mengestimasi dan menentukan magnitudo terbesar (MMax) dari masing-masing sumber gempa yang telah diidentifikasi sebelumnya.

d. Menentukan parameter gerakan tanah pada lokasi pengamatan dengan menggunakan fungsi atenuasi.

e. Menentukan controlling earthquake berdasarkan hasil perhitungan terbesar yang diperoleh guna mendapatkan nilai PGA di lokasi penelitian.

\section{HASIL DAN PEMBAHASAN}

\section{$5.1 \mathrm{HVSR}$}

\subsubsection{Frekuensi Dominan}

Peta sebaran nilai frekuensi dominan Kabupaten Cilacap dapat dilihat pada Gambar 2. Dari Gambar tersebut dapat diketahui frekuensi dominan Kabupaten Cilacap berada pada $0,44 \mathrm{~Hz}-$ 6,1 Hz. Secara umum, frekuensi dominan Cilacap didominasi dengan nilai $0,44 \mathrm{~Hz}-$ 1,57 Hz (warna ungu) yang berada di bagian Barat Daya, Selatan dan Tenggara Cilacap, yaitu di Kecamatan Kedungreja, Patimuan, Sidareja, Gandrungmangu, Cilacap Utara, Cilacap Selatan, Cilacap Tengah, Binangun, Kroya dan Nusawungun. Dominasi nilai frekuensi dominan yang rendah menandakan Wilayah tersebut memiliki keretanan terhadap bahaya gempa, karena mengacu pada Tabel 2 (Klasifikasi Kanai, 1983) tanah yang memiliki frekuensi dominan rendah $(<2,5 \mathrm{~Hz})$ merupakan tanah yang lapisan penyusunya sedimen yang sangat tebal (> $30 \mathrm{~m})$ dan lunak, yaitu lapisan yang dapat memperkuat getaran jika terjadi guncangan gempabumi.

\subsubsection{Amplifikasi}

Peta sebaran nilai amplifikasi di Kabupaten Cilacap dapat dilihat pada 
Gambar 3. Dari Gambar tersebut dapat diketahui bahwa amplifikasi di Kabupaten Cilacap berada di kisaran 1,104 - 8,171 kali. Secara umum, amplifikasi di Kabupaten Cilacap didominasi dengan nilai 4,629 - 8,171 kali. Nilai amplifikasi terbesar di Kabupaten Cilacap yaitu bernilai sekitar 8,31 kali pada titik C017 yang terdapat di Kecamatan Cilacap Selatan. Pada peta sebaran amplifikasi dapat diketahui sebagian besar Kabupaten Cilacap memiliki amplifikasi yang besar dan nilai amplifikasi yang besar berada pada daerah yang memiliki nilai frekuensi dominan rendah (Gambar 4).

Amplifikasi yang besa
menandakan tanah tersebut dapa memperkuat getaran akibat gempabumi karena lapisan penyusunya adalah sedimen lunak yang dapat memperlama durasi gelombang yang menjalar pada tanah sehingga terjadi pembesaran amplitudo pada gelombang dan hal ini berbahaya bagi pemukiman penduduk diatasnya. Daerah yang amplifikasinya besar ( $>4$ kali) di Kabupaten Cilacap adalah Kecamatan Nusawungun, Kroya, Adipala, Binangun, Cilacap Tengah, Cilacap Selatan,

Cilacap Utara, Gandrungmangu dan Kedungreja. Kemudian dengan mengkorelasikan peta geologi Kabupaten Cilacap (Gambar 1) maka daerah-daerah yang memiliki amplifikasi besar tersebut lapisan penyusunya adalah aluvial, lapisan yang tersusun oleh batuan sedimen berumur holosen. Kemudian hanya beberapa daerah yang memiliki amplifikasi $<4$ kali, terutama daerah yang berada di Utara dan Timur Laut Cilacap seperti Kecamatan Majenang, Cimanggu, Karangpucung, Cipari dan Dayeuh Luhur.

\subsubsection{VS30}

Peta sebaran nilai $V_{S 30}$ di Kabupaten Cilacap dapat dilihat pada Gambar 4. Dari peta tersebut dapat diketahui bahwa Kabupaten Cilacap memiliki nilai $V_{S 30}$ antara 18,49 - 732,41 $\mathrm{m} / \mathrm{s}$. Dengan didominasi oleh $V_{S 30}$ yang bernilai 18,49-161,28 m/s yang menyebar luas di bagian Barat Daya dan Selatan Kabupaten Cilacap yaitu Kecamatan Nusawungun, Binangun, Kroya, Cilacap Tengah, Cilacap Utara, Cilacap Selatan, Patimuan, Kedungreja dan Gandrungmangu.

Selanjutnya pada Gambar 5 dapat dilihat persebaran klasifikasi jenis tanah di Kabupaten Cilacap berdasarkan NEHRP (2000) yang menggunakan $V_{S 30}$ sebagai parameter klasifikasi. Diketahui bahwa Kabupaten Cilacap didominasi oleh tanah dengan Kelas E yang dikategorikan sebagai Soft Soil (Tanah Lunak) karena memiliki nilai $V_{s 30}$ yang sangat rendah yaitu dibawah 183 m/s. Terdapat pula tanah Kelas D yang berada di bagian Utara Kabupaten Cilacap. Tanah dengan Kelas D ini dikategorikan sebagai Stiff Soil (Tanah Keras) karena memiliki Vs antara 183 - 366 m/s. Secara geologi, menyebar luasnya tanah dengan Kelas E yang merupakan tanah lunak ini dapat dimaklumi karena Kabupaten Cilacap sendiri disusun oleh aluvium yang cukup tebal dan menyebar luas di sekitar Pantai Cilacap.

Dari klasifikasi NEHRP tersebut dapat diketahui bahwa hampir seluruh Kabupaten Cilacap tersusun oleh batuan yang lunak (NEHRP Kelas E: Soft Soil) yang tebal hingga kedalaman minimal 30 $\mathrm{m}$ dibawah permukaan. Hal ini makin memperjelas bahwa lapisan penyusun Cilacap adalah sedimen lunak yang akan berbahaya jika terjadi guncangan gempa.

\section{$5.2 \mathrm{DSHA}$}

\subsubsection{Subduksi Jawa}

Dapat dilihat pada Gambar 6 dan Gambar 7 merupakan peta sebaran nilai percepatan batuan dasar dan percepatan batuan permukaan berdasarkan sumber gempa Subduksi Jawa. Pada peta nilai percepatan batuan dasar memiliki nilai 
$P G A 0,045$ - 0,067 g. Kemudian pada batuan permukaan memiliki $P G A$ 0,19260,4855 g. Nilai $P G A$ sangat dipengaruhi oleh jarak dan megnitudo maksimum dari sumber gempa. Semakin dekat antara site dan sumber gempa maka nilai $P G A$ nya akan besar begitu sebaliknya. Daerah yang memiliki $P G A$ besar merupakan daerah bagian Selatan Cilacap, yaitu daerah sepanjang garis Pantai Cilacap yang merupakan daerah yang paling dekat dengan zona Subduksi Jawa, seperti

Kecamatan Nusawungun, Binagun, Adipala, Cilacap Tengah, Cilacap Selatan, Cilacap Utara.

Menurut klasifikasi (Kanai, 1983) tentang korelasi skala $M M I$ dengan $P G A$, maka nilai $P G A$ batuan dasar sumber subduksi berada pada skala $M M I$ IV - VI yang merupakan karakteristik gempa yang mengakibatkan kerusakan ringan pada bangunan dan dapat membuat lantai bangunan retak. Kemudian PGA batuan permukaan berada pada skala $M M I$ VII VIII yang memiliki ciri gempa dapat dirasakan semua orang, kendaraan dapat bergeser bahkan sudah dapat merobohkan bangunan yang lunak atau tidak kokoh.

Kemudian dapat diketahui dari nilai $P G A$ batuan dasar mengalami pembesaran pada nilai $P G A$ batuan permukaan, hal ini disebabkan nilai $P G A$ akan bertambah jika gelombang melalui lapisan yang awalnya keras ke lapisan lunak. Berdasarkan peta geologi Cilacap Gambar 1, wilayah Cilacap disusun formasi batuan sedimen yang berumur Miosen Akhir sampai Holosen yaitu batupasir, konglomerat, tufan, napal, breksi, andesit dan endapan aluvial yang merupakan batuan berumur muda dan memiliki densitas yang kecil serta merupakan lapisan yang tersusun tebal.

\subsubsection{Sesar Lembang}

Dari Gambar 8 dan Gambar 9 merupakan peta sebaran nilai $P G A$ batuan dasar dan batuan permukaan berdasarkan sumber gempa Sesar Lembang. Pada peta nilai percepatan batuan dasar memiliki nilai PGA 0,0091 - 0,0255 g. Kemudian pada batuan permukaan memiliki $P G A$ $0,0173-0,0887$ g. Nilai $P G A$ sumber Sesar Lembang lebih kecil dibanding nilai $P G A$ Subduksi Jawa, hal ini dikarenakan Subduksi Jawa memiliki nilai magnitudo maksimum 8,1 SR yang lebih besar dibanding Sesar Lembang yang memiliki magnitudo maksimum 6,8 SR. Daerah yang memiliki $P G A$ besar berdasarkan Sesar Lembang adalah daerah yang berada di sebelah Barat dan Barat Laut Cilacap yaitu Kecamatan Dayeuh Luhur, Wanareja, Majenang dan Kedungreja. Kecamatan kecamatan tersebut merupakan Kecamatan yang berdekatan dengan Provinsi Jawa Barat, karena lokasi Sesar Lembang berada di Kabupaten Lembang, Jawa Barat dan jarak Sesar Lembang ke Cilacap sekitar 90 $\mathrm{km}$.

Berdasarkan analisis frekuensi dominan, amplifikasi dan Vs30 Kecamatan Dayeuh Luhur dan Wanareja merupakan daerah yang tidak berbahaya jika terjadi gempa, namun pada analisis $P G A$ berdasarkan Sesar Lembang merupakan daerah yang memiliki nilai paling besar, hal ini dikarenakan daerah tersebut merupakan yang paling dekat dengan Sesar Lembang, hal ini memperjelas bahwa dalam analisa metode deterministik, jarak merupakan parameter utama yang sangat menentukan nilai percepatan puncak tanah.

\subsection{Konsep Resiko Bencana}

\subsubsection{Analisis Tingkat Bahaya}

Untuk mendapatkan gambaran tingkat bahaya bencana gempabumi di wilayah Kabupaten Cilacap digunakan data karakteristik dinamika tanah berdasarkan hasil pengolahan mikrotremor yaitu parameter masukan nilai amplifikasi dan 
frekuensi dominan. Klasifikasi analisis ini dapat dilihat pada Tabel 1. Kemudian hasil analisis dapat dilihat pada Gambar 10. Dimana pada klasifikasi ini dibagi menjadi 3 kelas, yaitu rendah, sedang dan tinggi. Cilacap didominasi daerah bahaya tinggi.

\subsubsection{Analisis Tingkat Kerentanan}

Untuk mendapatkan gambaran umum tingkat kerentanan bencana digunakan data kepadatan penduduk tiap kecamatan di Kabupaten Cilacap. Tingginya kepadatan penduduk mengakibatkan semakin tinggi pula kemungkinan banyaknya korban jiwa maupun materi. Data yang digunakan untuk analisis ini adalah data dari BPS (2015). Peta sebaran analisis ini dapat dilihat pada

\section{Gambar 11.}

\subsubsection{Analisis Tingkat Kemampuan}

Salah satu gambaran yang digunakan dalam menganalisis tingkat kemampuan dalam menghadapi gempabumi adalah adanya ketersediaan sarana dan prasarana kesehatan di suatu daerah. Dalam penelitian ini, digunakan data jumlah tenaga paramedis yang tersebar di setiap kecamatan di Wilayah Kabupaten Cilacap PPSDM (2015). Peta sebaran analisis ini dapat dilihat pada Gambar 12.

\subsubsection{Analisis Tingkat Resiko}

Tingkat risiko bencana gempabumi merupakan gabungan antara faktor tingkat bahaya, kerentanan dan kemampuan dalam menghadapi bencana yang dapat dilihat pada Gambar 13. Hubungan antara nilai frekuensi dominan, amplifikasi, jumlah kepadatan penduduk dan jumlah tenaga kesehatan serta tingkat potensi risiko gempabumi dapat dilihat Tabel 2. Klasifikasi ini dibagi menjadi 3 kelas, yaitu rendah, sedang dan tinggi. Cilacap didominasi daerah resiko tinggi, dengan daerah resiko tinggi memiliki kriteria amplifikasi tinggi (>4 kali), frekuensi rendah $(<2,5 \mathrm{~Hz})$, kepadatan penduduk tinggi ( $>1000$ jiwa $/ \mathrm{km}^{2}$ ) dan tenaga kesehatan rendah ( $<20$ orang/kecamatan).

\section{KESIMPULAN DAN SARAN}

\subsection{Kesimpulan}

Dari hasil penelitian ini dapat ditarik beberapa kesimpulan, yaitu:

1. Berdasarkan analisis metode HVSR didapat nilai frekuensi dominan Kaupaten Cilacap 0,44 - 6,01 Hz dengan jenis tanah II - IV berdasar pada klasifikasi Kanai (1983). Amplifikasi Kabupaten Cilacap 1,104 - 8,171 kali, amplifikasi tertinggi berwarna biru pada Gambar 4 yang dominan pada pada Kecamatan Nusawungun, Kroya, Adipala, Cilacap Tengah, Cilacap Selatan, Kedungreja, Gandrungmangu dan jeruklegi. Nilai kecepatan gelombang Vs30 berkisar 18,49 - 732,41 $\mathrm{m} / \mathrm{s}$ dan didominasi nilai 18,49-161,28 $\mathrm{m} / \mathrm{s}$, berdasar pada NEHRP (2000) Kabupaten Cilacap didominasi kelas tanah E (tanah lunak) dan kelas tanah D (tanah keras).

Berdasarkan metode DSHA, hasil analisis berdasar pada sumber Subduksi Jawa didapat nilai PGA batuan dasar 0,045 - 0,0671 g dan PGA batuan permukaan $0,1926-0,4855 \mathrm{~g}$. Kemudian pada sumber Sesar Lembang didapat nilai PGA batuan dasar 0,0091 - 0,0255 g dan PGA batuan permukaan $0,0173-0,0887$ g. Nilai PGA paling tinggi berada pada skala MMI VII-VIII.

2. Berdasarkan peta tingkat resiko, Kabupaten Cilacap berada pada tingkat resiko rendah sampai tinggi, didominasi tingkat resiko sedang sampai tinggi. Pada Gambar 15 tingkat resiko tinggi berada pada Kecamatan Nusawungun, Binangun, Adipala, Cilacap selatan, Cilacap Tengah, Cilacap Utara, 
Kasugihan, Patimuan dan Kedungreja. Lapisan penyusun dari daerah beresiko tinggi merupakan endapan aluvial.

\subsection{Saran}

Pada survei Mikrotremor, selain pengukuran menggunakan seismometer, pengukuran perlu dilakukan dengan menggunakan Accelerometer agar nilai $P G A$ dapat diketahui secara langsung. Kemudian Untuk pengembangan penelitian analisis seismic hazard selanjutnya diperlukan data pendukung seperti data bor untuk mengetahui jenis tanah secara tepat pada setiap lapisan sehingga hasil yang didapatkan diharapkan mampu memberikan hasil yang lebih akurat.

\section{DAFTAR PUSTAKA}

Arifin, S.S., B.S. Mulyatno, Marjiyono, dan R. Setianegara. 2014. Penentuan Zona Rawan Guncangan Bencana Gempa Bumi Berdasarkan Analisis Nilai Amplifikasi HVSR Mikrotremor dan Analisis Periode Dominan Daerah Liwa dan Sekitarnya. Jurnal Eksplorasi Geofisika 2 (1): 30-40.

\section{BAKORNAS PB.2007. Pengenalan}

Karakteristik Bencana dan Upaya

Mitigasinya di

Pelaksana Harian

Indonesia.

Koordinasi Nasional Penanganan Bencana. Edisi II. Jakarta Pusat.

Daryono, Sutikno, Sartohadi, Dulbahri, Brotopuspito. 2009. Pengkajian Lokal Site Effect di Graben Bantul Menggunakan Indeks Kerentanan Seismik Berdasarkan Pengukuran Mikrotremor. Jurnal Kebencanaan Indonesia, 2(1) : 456-467.

Djuri. 1995. Peta Geologi Lembar Arjawinangun, Jawa, Skala $1: 100.000$.
Pusat Penelitian dan

Pengembangan Geologi. Bandung.

Hadi, A.I., M. Farid, dan Y. Fauzi. 2012. Pemetaan Percepatan Getaran Tanah Maksimum dan

Kerentanan Seismik Akibat Gempa Bumi untuk Mendukung Rencana Tata Ruang dan Wilayah (RTRW) Kota Bengkulu. Jurnal Ilmu Fisika Indonesia 1 (2): 81-86.

Kanai, K. 1983. Engineering Seismology. University of Tokyo Press. Tokyo.

Kramer, S.L. 1996. Geotechnical Earthquake Engineering. Prentice Hall. Upper Saddle River, New Jersey.

Kusumaningsih, H. 2004. Studi Respon Permukaan Lokal di Sambisari, Kalasan,Sleman dengan Menggunakan Teknik Horizontal to vertical Spectral Ratio (HVSR) dari Gelombang Seismik. Skripsi S-1 Program Studi Geofisika. FMIPA UGM. Yogyakarta.

Makrup, L. 2013. Seismic Hazard untuk Indonesia. Graha Ilmu. Yogyakarta.

Morikawa, N., S. Senna, Y. Hayakawa, dan

H. Fujiwara. 2008. Application and Verification of The 'Recipe'to StrongMotion Evaluation for The 2005 West Off Fukuoka Earthquake (Mw= 6.6). Proceedings $14^{\text {th }}$

World Conference Earthquake Engineering (02-0039).

Nakamura, Y. 2008. On The H/V Spectrum. The $14^{\text {th }}$ World Conference on Earthquake Engineering. Beijing, China.

National Earthquake Hazards Reduction Program. 2000. International Building Code. International Code Council. United States of America.

Nurrahmi, R. Efendi, dan Sandra. 2015. Analisis Kecepatan Gelombang Geser Vs30 Menggunakan Metode Refraksi Mikrotremor 
(ReMi) di Kelurahan Talise.

Gravitasi 14 (1).

Rosyidi, S.A.P., T.A. Jamaluddin, L.C.

Sian, dan M.D. Taha. 2011

Kesan Gempa 7,6 Mw Padang Indonesia, 30 September 2009. Sains Malaysiana 40 (12): 1393-1405.

Susilanto, P., dan Ngadmanto, D. 2014. Analisis Kecepatan Gelombang Geser(Vs) di Cilacap, Jawa Tengah Sebagai Upaya Mitigasi Bencana Gempabumi. Pusat Penelitian dan Pengembangan, Badan Meteorologi Klimatologi dan Geofisika, Jakarta.

Tim Revisi Peta Gempa Indonesia. 2010. Ringkasan Hasil Studi Tim Revisi Peta Gempa Indonesia.

Zhao, J.X. dan H. Xu. 2012. Calibration of a Combined Site Parameter of Vs30 and Bedrock Depth for Ground Motion PredictionEquations Using Strong- Motion Records from Japan. $15^{\text {th }}$ World Conference Earthquake Engineering. 
Tabel 1. Klasifikasi tingkat bahaya gempabumi berdasarkan nilai amplifikasi dan frekuensi dominan Kabupaten Cilacap.

\begin{tabular}{|c|c|c|}
\hline Nilai Amplifikasi & Nilai Frekuensi Dominan $(\mathrm{Hz})$ & \multirow{2}{*}{ Tingkat Bahaya } \\
\hline $1,1041-8,171$ & $0,44 \mathrm{~Hz}-6,11 \mathrm{~Hz}$ & Rendah \\
\hline$\leq 3,0$ & $\geq 4,1$ & Sedang \\
\hline $3,1-6,0$ & $1,6-4,0$ & Tinggi \\
\hline$\geq 6,1$ & $\leq 1,5$ & \\
\hline
\end{tabular}

Tabel 2. Klasifikasi tingkat resiko gempabumi Kabupaten Cilacap

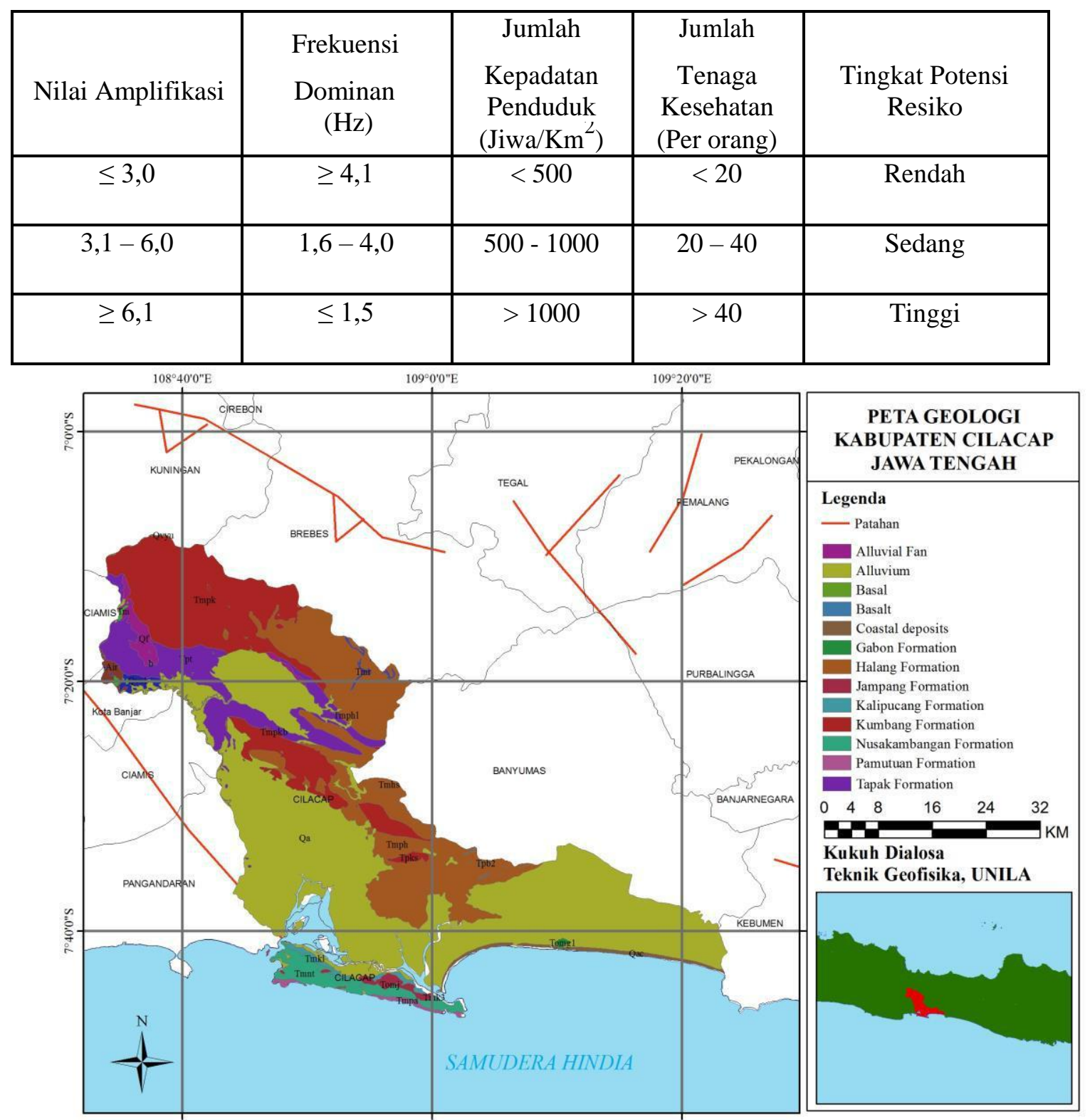

Gambar 1. Peta Geologi Kabupaten Cilacap, Jawa Tengah (Modifikasi dari Djuri, 1995). 


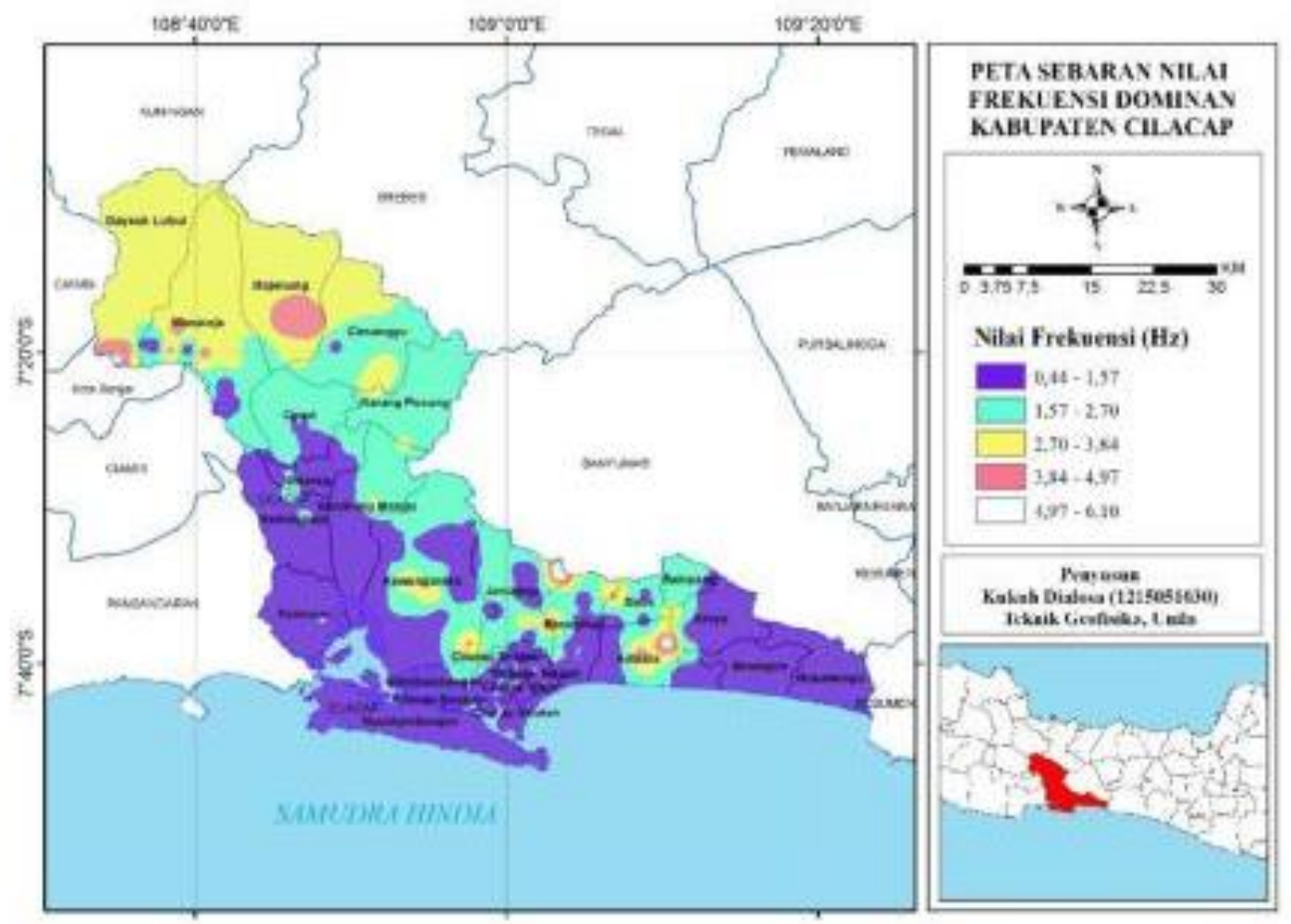

Gambar 2. Peta sebaran nilai frekuensi dominan.

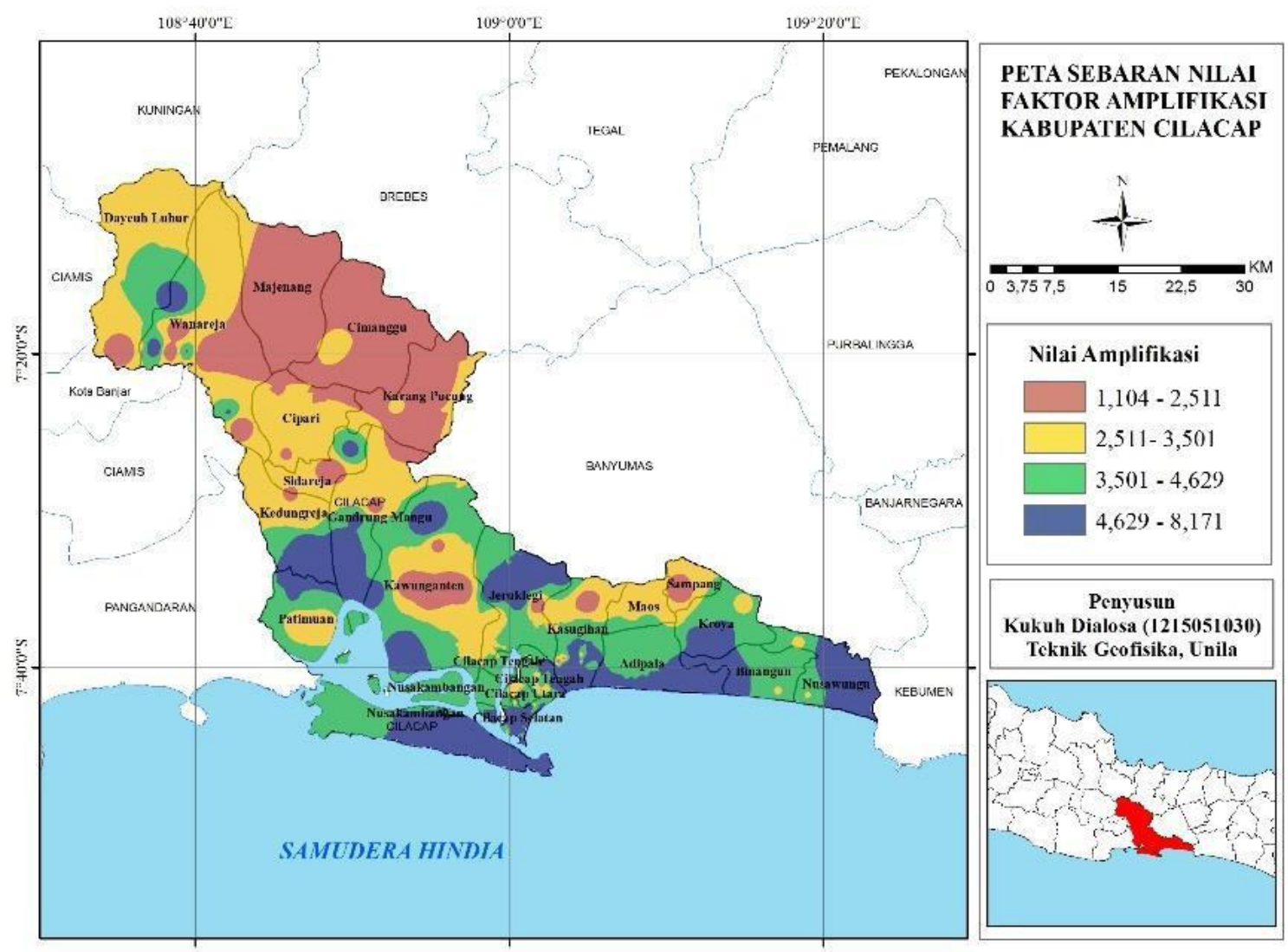

Gambar 3. Peta sebaran nilai amplifikasi. 

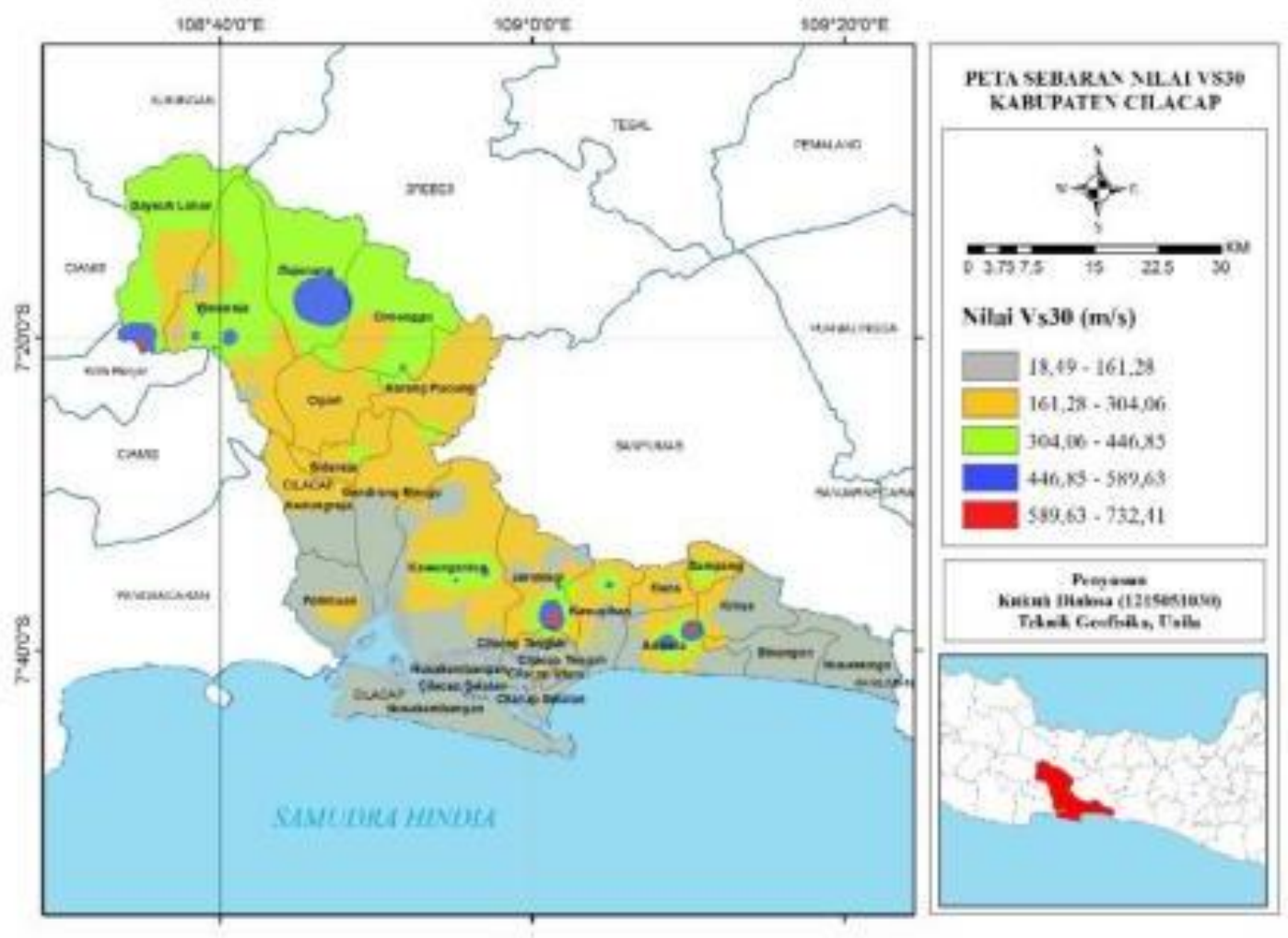

Gambar 4. Peta sebaran nilai $V_{S 30 .}$
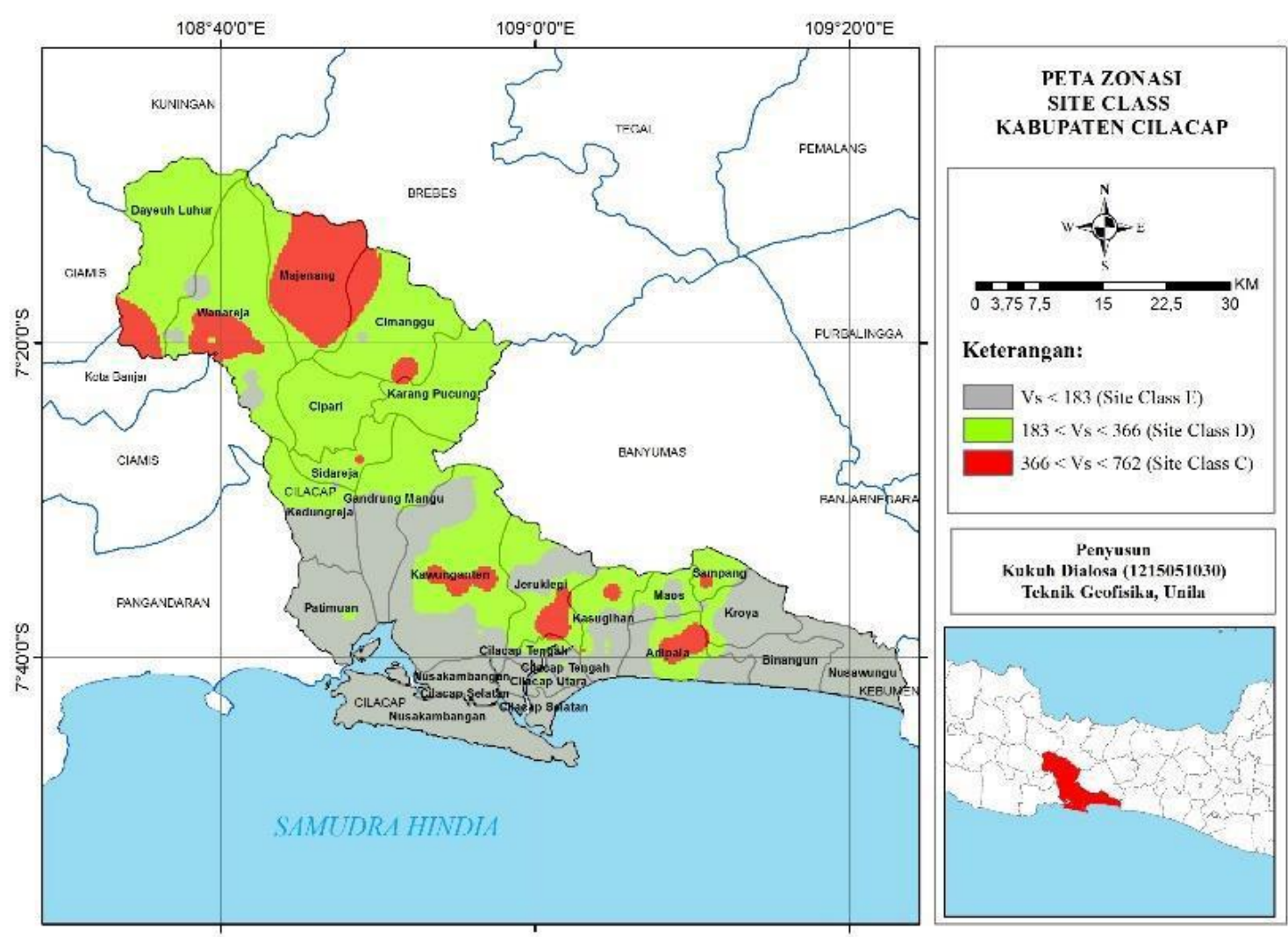

Gambar 5. Peta site class Kabupaten Cilacap. 

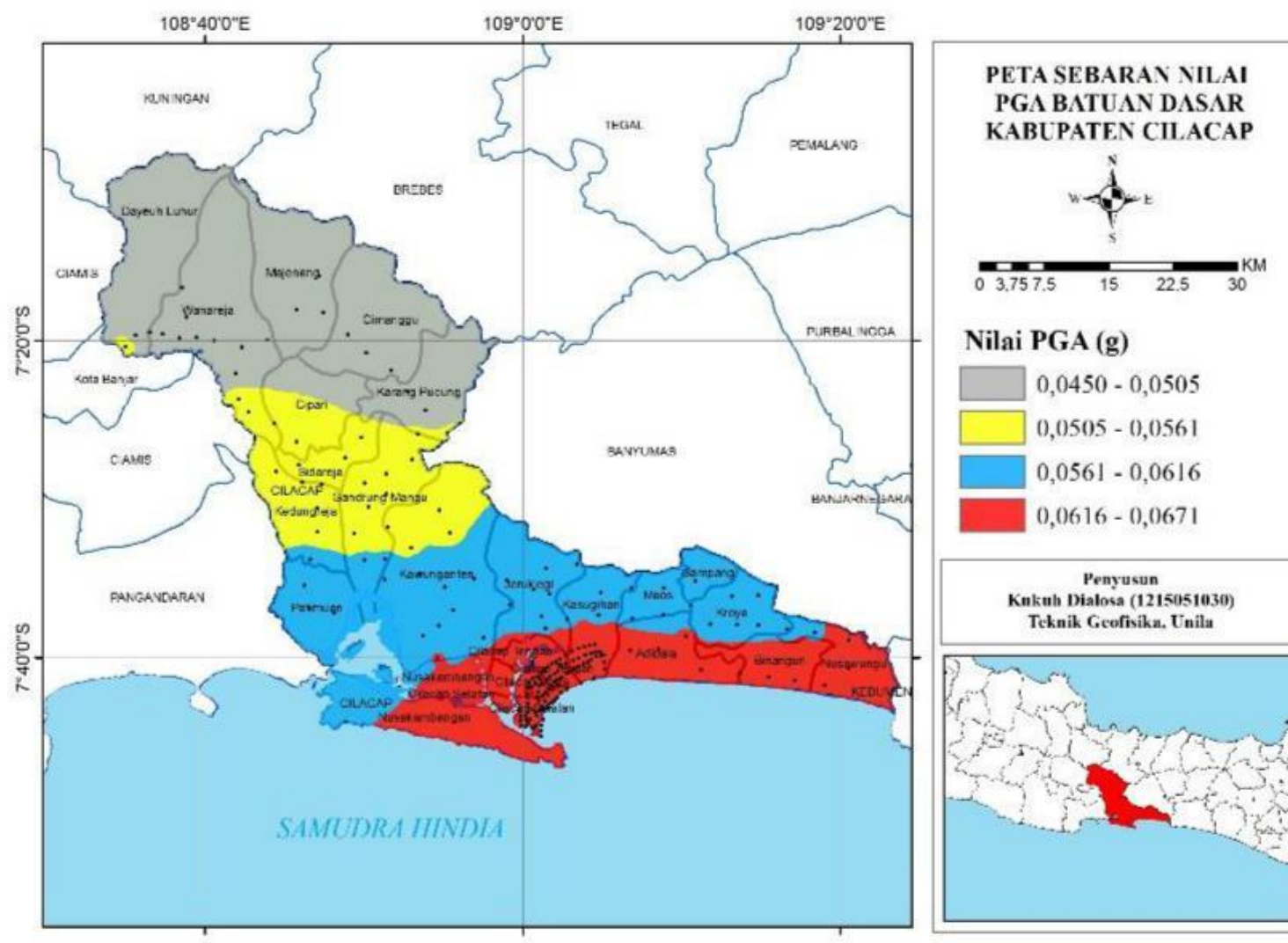

Nilai PGA (g)
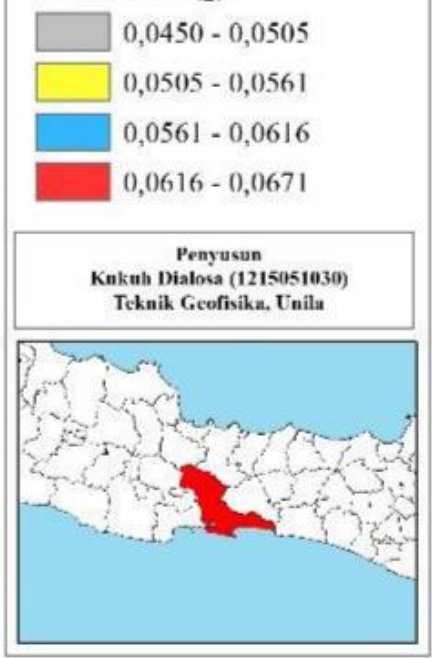

Gambar 6. Peta sebaran nilai PGA batuan dasar (Subduksi Jawa).

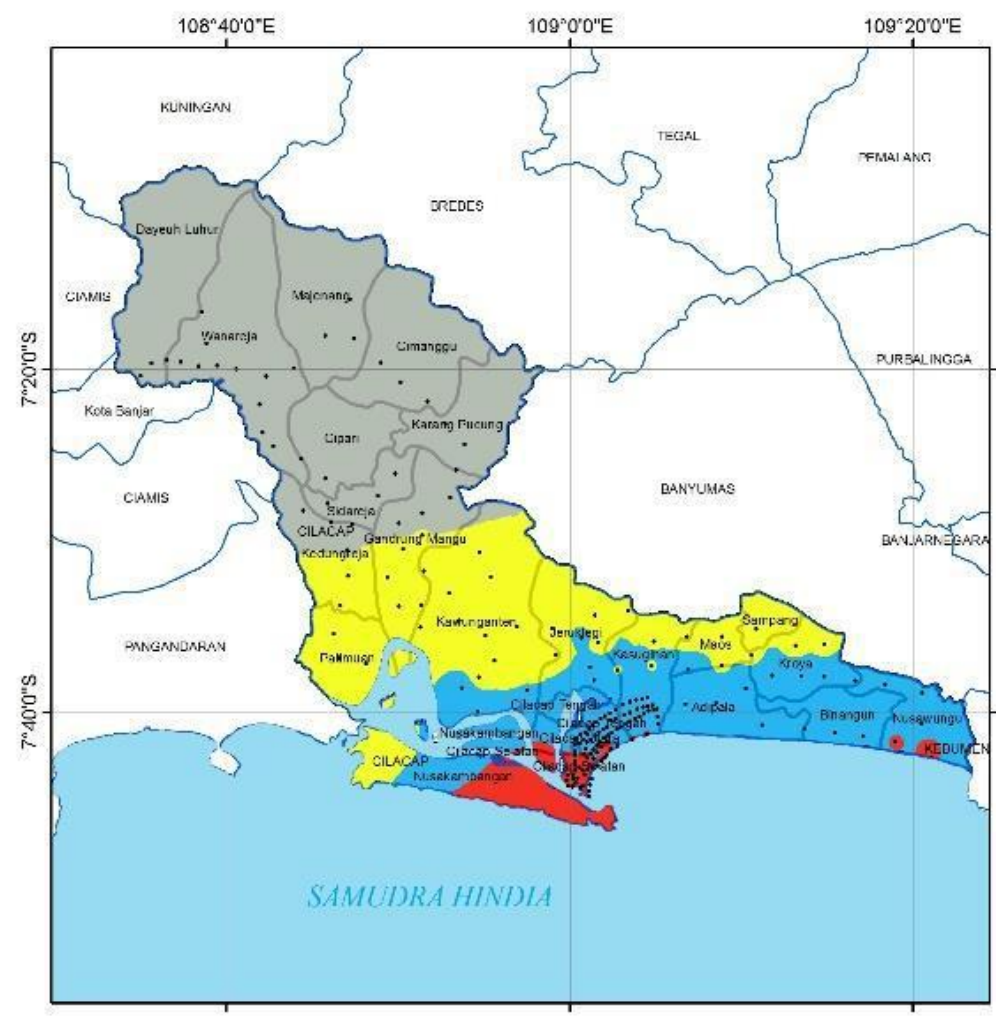

PETA SEBARAN NILAI

PGA BATUAN PERMUKAAN SUBDUKSI JAWA

KABCPATEN CILACAP

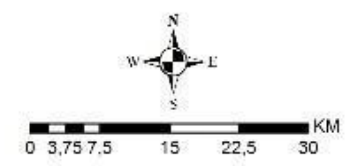

\section{Nilai PGA (g)}

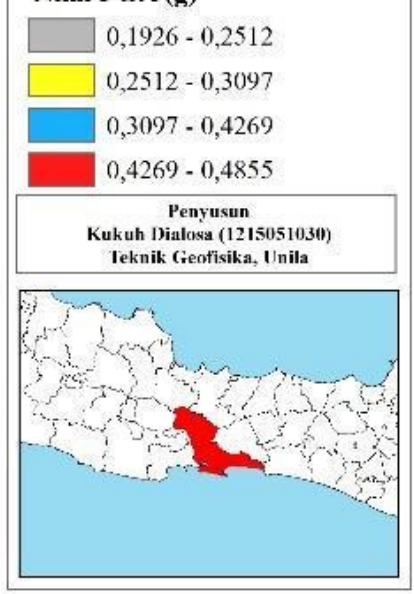

Gambar 7. Peta sebaran nilai PGA batuan permukaan (Subduksi Jawa). 

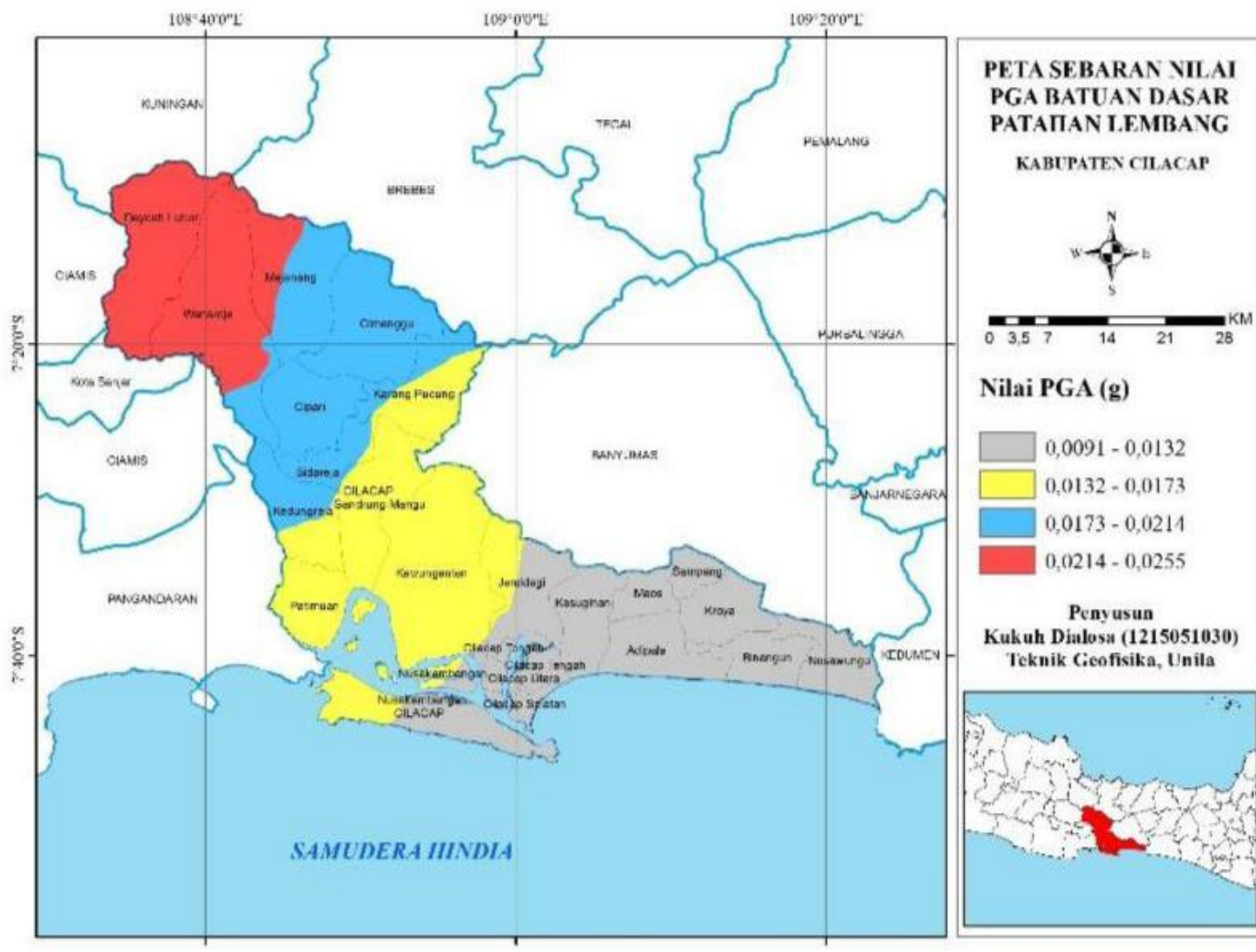

\section{Nilai PGA (g)}

$0,0091-0,0132$

$0,0132-0,0173$

$0,0173-0,0214$

$0,0214-0,0255$

Penyusun

Kukuh Dialosa (1215051030) Teknik Cieofisika, Unila

Gambar 8. Peta sebaran nilai $P G A$ batuan dasar (Sesar Lembang).

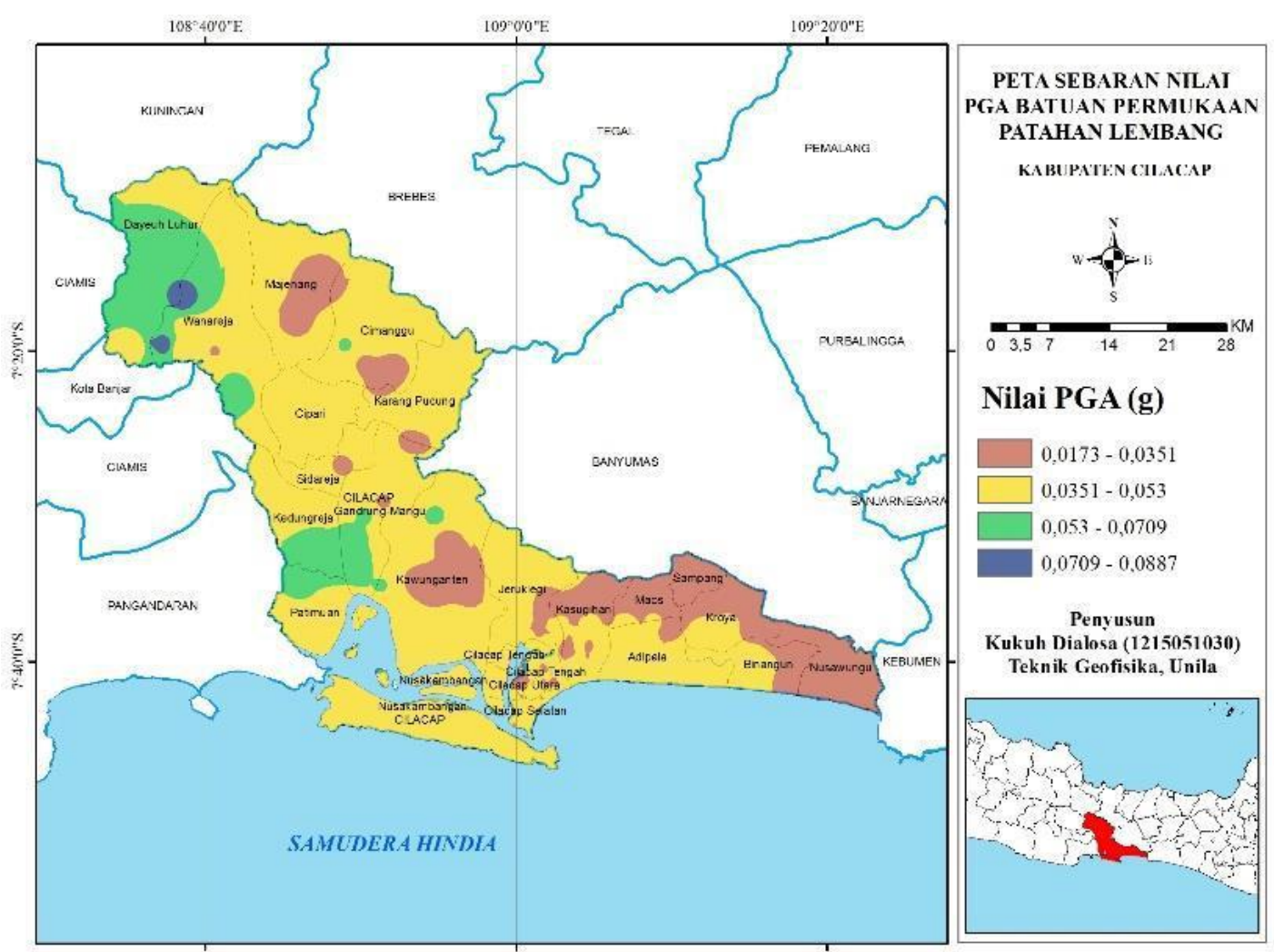

Gambar 9. Peta sebaran nilai $P G A$ batuan permukaan (Sesar Lembang). 

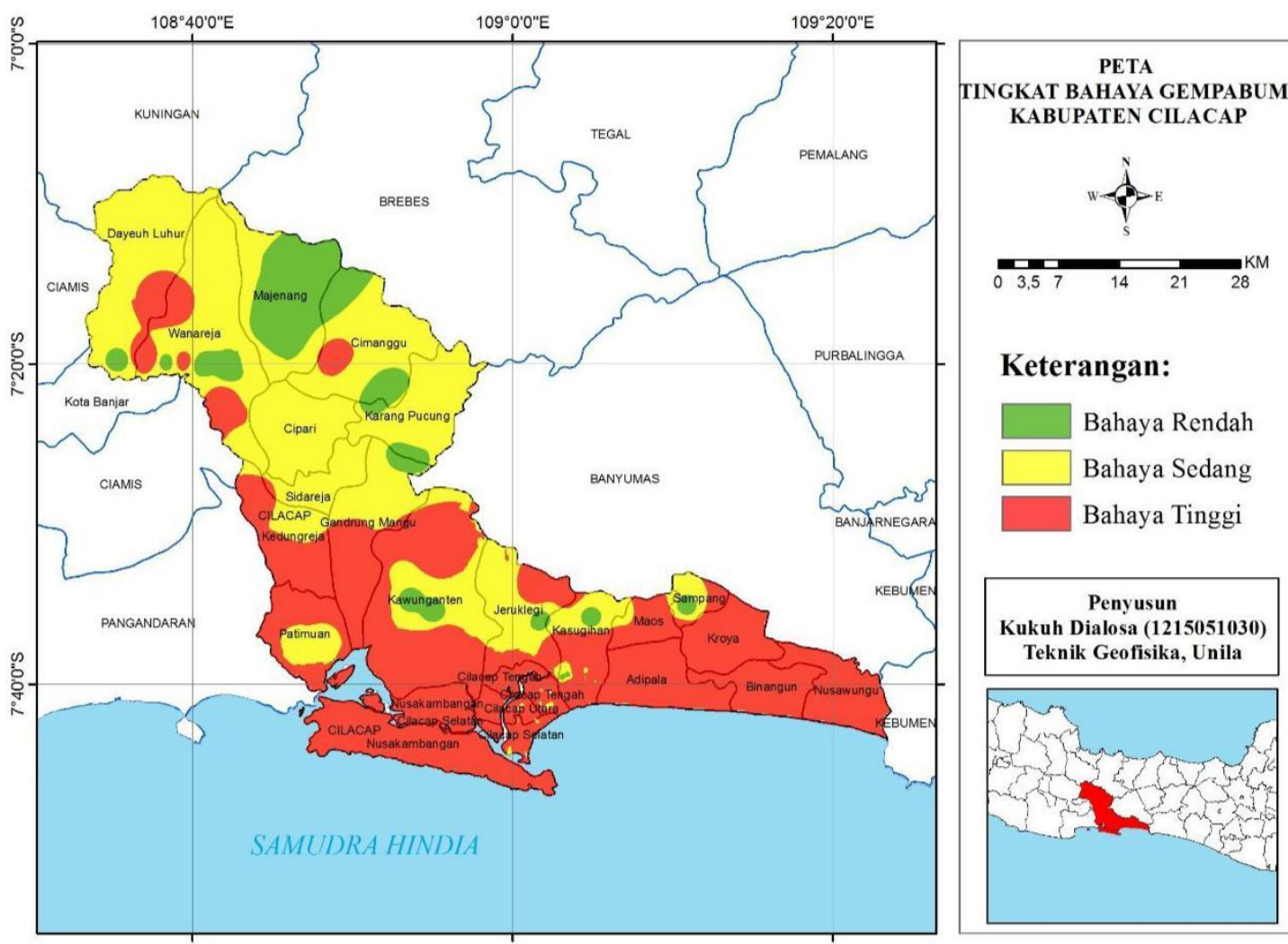

\section{Keterangan:}
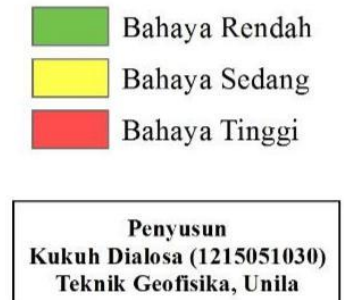

Teknik Geofisika, Unila

Gambar 10. Peta tingkat bahaya gempabumi Wilayah Kabupaten Cilacap.

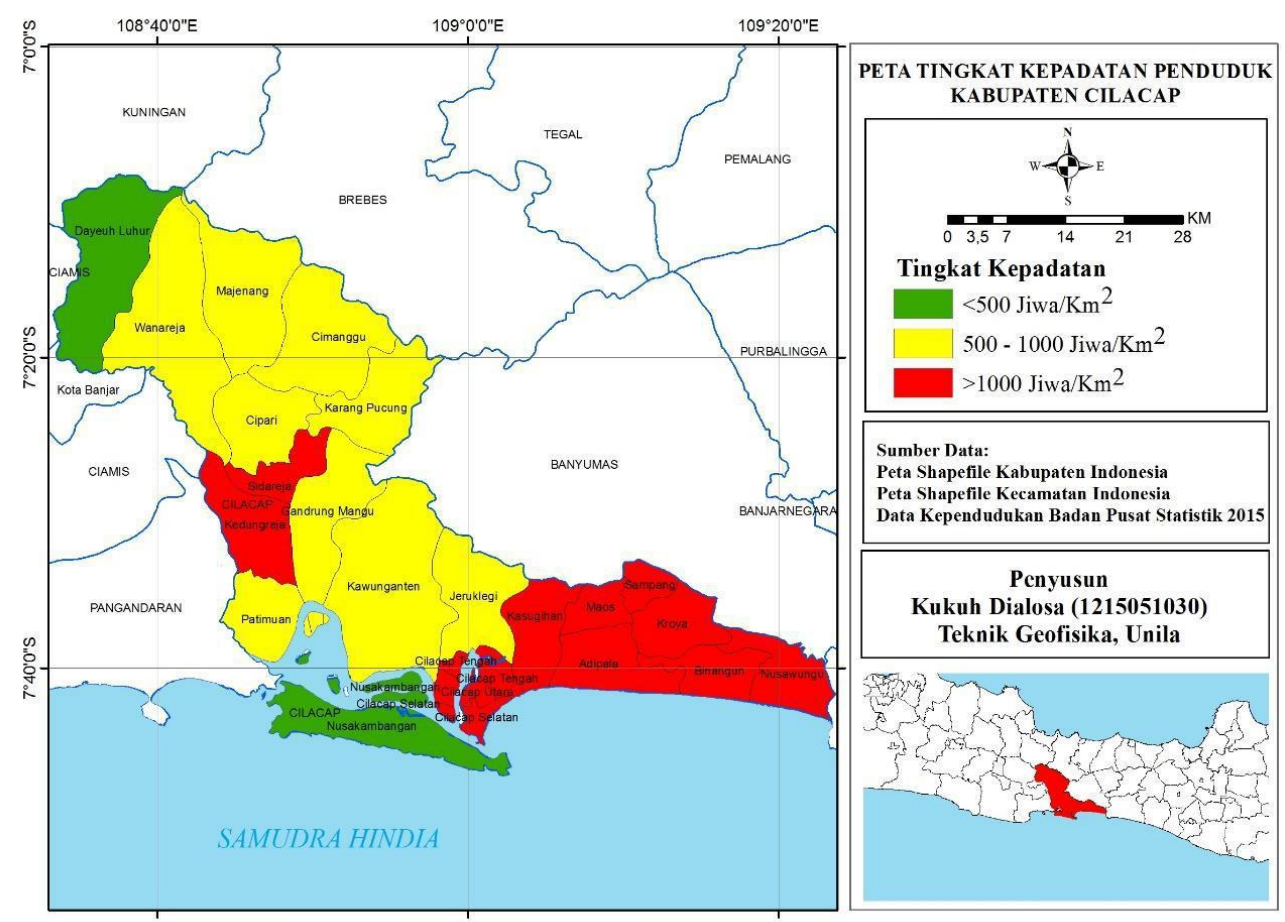

Gambar 11. Peta tingkat kepadatan penduduk Perkecamatan Wilayah Kabupaten Cilacap. 

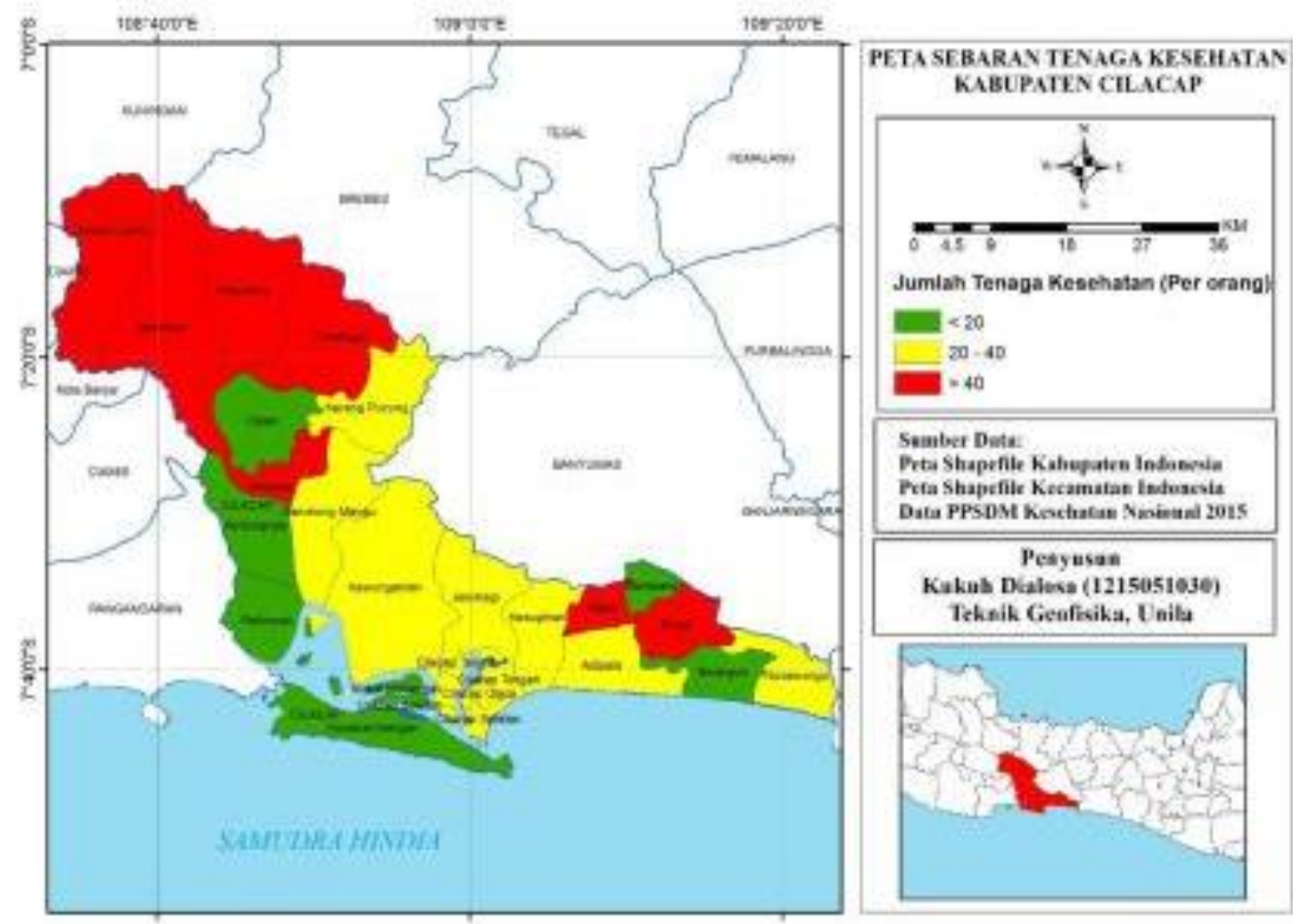

Gambar 12. Peta jumlah tenaga kesehatan yang tersebar di setiap Kecamatan Wilayah Kabupaten Cilacap.
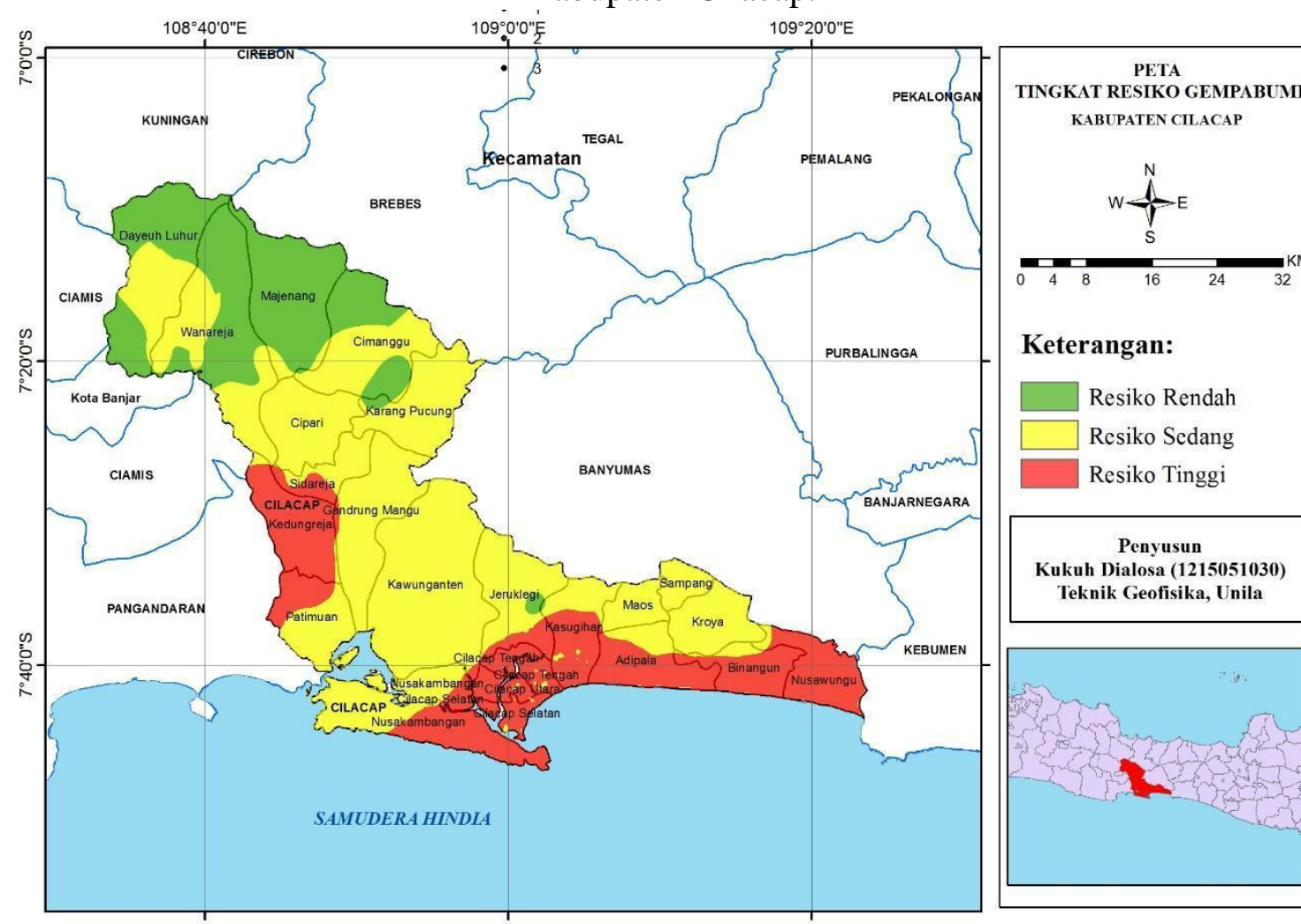

Keterangan:
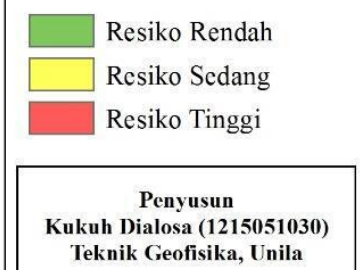

Gambar 13. Peta tingkat resiko gempabumi Wilayah Kabupaten Cilacap. 